\title{
The biggest Polish cities in response to the first wave of the COVID-19 pandemic. The perspective of municipal self-government administration
}

\begin{abstract}
The aim of the article is to analyze the activities of municipal self-government administration aimed at counteracting the destructive effects of the COVID-19 pandemic during the co-called first wave of the COVID-19 pandemic (March 2020-June 2020). The article focuses on Polish cities with poviat rights. It presents the results of a nationwide survey in which the representatives of 47 city offices participated. It is supplemented with the analysis of the content of documents (laws, regulations and recommendations) and the elements of a comparative analysis. The conducted research procedure does not allow to confirm the hypothesis. There is no scheme of the response to the COVID-19 pandemic which consists of "bottom-up" activities of municipal self-government carried out in the areas of urban policy which are most affected by the COVID-19 pandemic. It turns out that most of the activities carried out are "top-down" activities that fit - as the respondents claimed - with the solutions adopted by the central government administration.
\end{abstract}

Key words: COVID-19 pandemic, Poland, cities, municipal self-government administration

\section{Introduction}

D ue to the crisis of the modern democratic state, understood as the functional erosion of the traditional highly centralized and hierarchical structure, other and not so obvious levels and forms of organization of political, economic and social life gain significance (Bartolini, 2015, p. 381). The dynamic and turbulent and thus not fully controlled processes of territorial autonomy lead to the situation in which cities, especially the biggest cities, face the difficult task of redefining the existing priorities and mechanisms of functioning. The COVID-19 pandemic is undoubtedly an extremely serious and thus unknown challenge faced by cities. The COVID-19 pandemic is important as it 'paralyzes', in an unprecedented and unexplored scale, the contemporary urban policy defined as a complex of activities targeted at meeting the needs of residents (World Health Organization, 2020a). Therefore due to the COVID-19 pandemic many areas of urban policy (e.g. health care, social care, labor market, housing, education, culture, recreation, transport, etc.) fall into an organizational and financial crisis (cf. Jones, 2019). It can be observed, among others, in a difficult care for the sick, elderly and disabled in hospitals and health clinics, increase in unemployment, deterioration of working conditions, loss of residence, closing of schools, closing of recreational and sports facilities, cancellation of performances and concerts, suspension and/or organized transport connections (see Honey-Roses, 2020). What is more, the results of the latest research clearly show that it is the big cities, due to their population potential and the enormous intensity 
of interpersonal contacts, that are particularly exposed to the destructive consequences of the COVID-19 pandemic (Stier et al., 2020; Awasthi, Mavlankar, 2020; Ribeiro et al., 2020). This situation in a 'natural' way provokes the question about the reaction of the municipal self-government administration to the challenges related to counteracting the destructive effects of the COVID-19 pandemic.

The actions of local government administration in the largest Polish cities (cities with poviat status), which fall within the so-called first wave of the pandemic (period between March 2020 and June 2020), seem to be an interesting example of this reaction. ${ }^{1}$ This is determined by at least three factors of an exogemic (in relation to the cities themselves) character.

First of all, it is worth to consider the relatively quick decision of the Polish government to introduce a nationwide lockdown. In the second place, it should be emphasized that the pandemic development (measured by the number of SARS-CoV-2 coronavirus infections), treated as a result of the aforementioned decision, should be stopped rapidly. The third, equally important factor can be observed in the lack of systemic legal and organizational solutions which, adopted by the Polish government, would comprehensively compensate for the destructive effects of the COVID-19 pandemic on the functioning of cities and their inhabitants. ${ }^{2}$

It should be noted that the so-called first wave of the COVID-19 pandemic in Poland had much less serious consequences, both in terms of health, economic and social issues, than could be observed in other European countries, e.g. in Italy. For this reason, it is impossible to really compare the reaction of the local municipal administration with the reaction observed in countries much more "experienced" by the spread of the SARS-CoV-2 coronavirus. Moreover, it is worth paying attention to the fact that the reaction to the so-called first wave of the COVID-19 pandemic "did not reveal" all the activities taken by municipal self-government administrations - a significant part of these activities fell only on the so-called second wave of the COVID-19 pandemic which is not the subject of these considerations.

Nevertheless, there is no doubt that one talks about such activities initiated by the Polish municipal self-government administration which go beyond the current local government practice. Obviously, one can enumerate many examples of municipal government activities aimed at "fighting" the epidemic, for example in West African countries struggling with the Ebola virus (see Masci, Bass, 2017; Idris, Fagbenro, 2019), or in Asian countries - with the SARS virus (see Lam, Zong, Tam, 2003; Qui et al., 2018). In the post-war history of Poland, however, it is difficult to point to a situation, perhaps apart from the smallpox epidemic in Wrocław in 1963, which would destabilize the

1 The term 'first wave of a pandemic' is obviously blurred. Some researchers argue that the division of the pandemic into phases is unjustified. The specified period (March 2020-June 2020) is therefore treated conventionally as the so-called first wave of a pandemic, in line with the statement of the Minister of Health of the Republic of Poland (Zimny-Zając, 2020, August 18th).

${ }^{2}$ Although the decision to introduce the lockdown was accompanied by a number of protective (aid) measures adopted in the form of an act, they did not implement many of the postulates formulated by local governments, including Association of Polish Cities (Pol. Związek Miast Polskich). One of them was to equip local governments with legal and organizational instruments that could effectively "cushion" the destructive impact of the COVID-19 pandemic (Government of the Republic of Poland, 2020; Association of Polish Cities, 2020a). 
functioning of cities to the same or even comparable extent as it was in West Africa and Asia (see Trzaskowska, 2008). In this sense, the so-called first wave of the COVID-19 pandemic in Poland can be treated as a challenge with unprecedented repercussions.

\section{Literature review and research design}

The municipal self-government administration is, obviously, the most important actor of contemporary urban policy. Nevertheless, this claim requires a few remarks.

Firstly, municipal self-government administration does not operate only in one classically understood scale. A review of the vast subject literature allows us to believe that it undertakes much more extensive and spatially diversified activities. The essence of this change is reflected in the concept of rescaling which is a part of this trend of scientific reflection which emphasizes the growing role and importance of contemporary cities (Gleaser, 2011). The explanatory potential of the research by Erik Swyngedouw, Neil Brenner, or Marta Lackowska should be emphasized here (Swyngedouw, 1997, 2004; Brenner, 1998, 2001, 2003, 2014, 2019; Lackowska, 2010, 2014).

Secondly, the implementation of development activities also integrates the activity of these actors which goes beyond the traditional (classic) understanding of 'political'. In this case, one talks about private actors (entrepreneurs, investors, etc.) and non-governmental (non-governmental organizations, informal groups, social leaders, etc.). It is therefore about the approaches that emphasize the possibilities arising from the development of mechanisms of intersectoral cooperation. The findings of the advocates of the urban regime theory ${ }^{3}$ seem to be particularly valuable, including Stephen L. Elkin (1987), Clarence N. Stone (1989, 1993), Gerry Stoker and Karen Mossberger (1994, 2001), David L. Imbroscio (1998), Iwona Sagan (2000). The works of public governance researchers, including Roderick A. W. Rhodes (1993, 1994, 1997), Calus Offe (2009), Anne Mette Kjaer (2009), Jacek Sroka (2008), Katarzyna Radzik-Maruszak (2019), Agnieszka Pawłowska (2019) should be considered equally valuable.

Thirdly, among actors of urban policy one can also list the institutions and bodies operating at international, central (government) and regional levels. The activity of these entities is in line with the assumptions of the Multi-level Governance (MLG) concept which occupies an important place in social research, including political science (see Jordan, 2001; Hooghe, Marks 2003; Jessop, 2013; Gonzalez Medina, Fedeli, 2015).

It should be emphasized that the author's attention is focused only on those activities of municipal self-government administration that are carried out in a classic, typically "urban" scale. Moreover, the author deliberately omits the threads of cooperation of the city council with social and private actors. In this sense, the aforementioned concept of rescaling, like the aforementioned theories of urban regime and governance, although extremely useful and widely commented on in the literature on the subject, do not form the framework of the article. On the other hand, the analysis of the extent of "overlapping" between the activities of the municipal self-government administration and the ac-

${ }^{3}$ The relationships between public, private and social entities that operate at the local level are the subject of interest of advocates of the theory of the urban regime. The most important assumptions of this theory have been presented in the author's earlier works (see Glinka, 2020b, pp. 40-49, 2020c). 
tivities of the central government administration aimed at counteracting the destructive consequences of the COVID-19 pandemic plays a special role (see Figure 1).

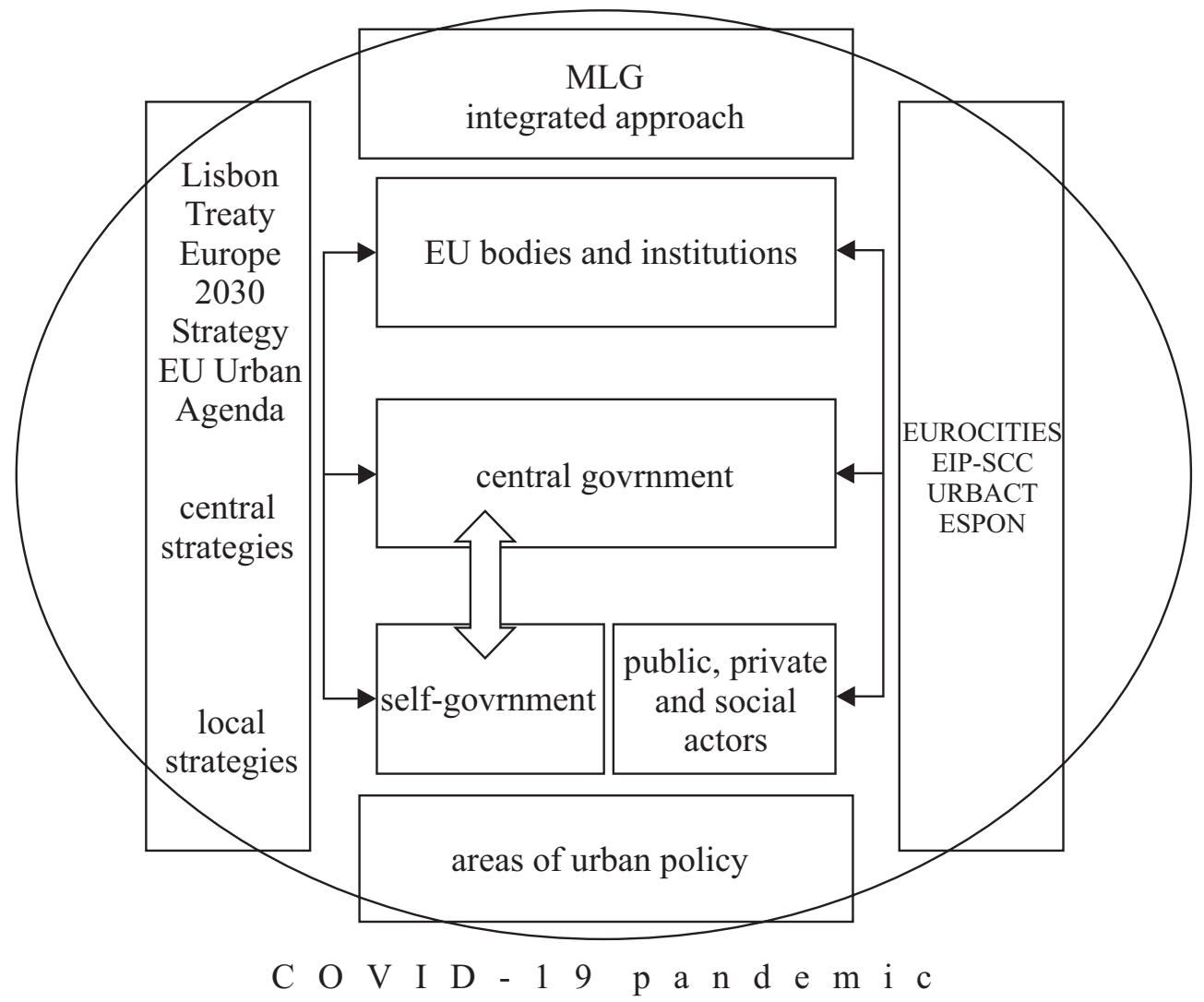

Fugure 1. Urban policy system within the COVID-19 pandemic - the "tension" between municipal self-government adminstration and central government adminstration

Source: Author's own compilation on the basis of: Glinka, 2020b, p. 75.

Bearing in mind the above, one may be tempted to say that the analysis "touches" the MLG concept although only to a limited extent, because the key role is actually played by the delimitation of the "tension" between the urban level and the central (government) level. In this sense, the dominant context of considerations is determined by the perspective of local autonomy. In this case, one talks about the potential for activities which characterizes local governments and is a derivative of systemic (political) conditions. A review of the vast subject literature shows that the local government in Poland, including the municipal self-government, is characterized by a relatively wide range of decision and organizational autonomy. According to the research of an international team led by Andreas Ladner, Nikolas Keuffer and Harald Baldersheim, Poland is in the group of countries that provide local self-governments with a relatively wide range of autonomy, as evidenced by the indication of 25 points and more according to the Local Autonomy Index/LAI (Ladner, Keuffer, Baldersheim, 2016; cf. Ladner et al., 2019). The 
high position is also confirmed in the analyzes by Paweł Swianiewicz (2019). Therefore, this assessment naturally provokes the question about the activities of municipal selfgovernment administration in the period of the so-called first wave of the COVID-19 pandemic, or rather its ability to operate in this field relatively "independently."

For the purposes of the article, a research perspective is adopted that can be described as the perspective of political actors ${ }^{4}$ (see Mair, 1999; Młyniec, 2004a, 2004b). Therefore, an analysis of the activities of these actors, i.e. municipal self-government administration based on their observations and opinions is the foundation of the research procedure.

This does not mean that the author of this article ignores numerous reports that provide valuable information on the activities of municipalities during the so-called first wave of the COVID-19 pandemic (see United Nations, 2020; World Health Organization Europe, 2020; Organization for Economic Cooperation and Development, 2020c, 2020d, 2020e; European Committee of the Regions, 2020; EUROCITIES, 2020; Association of Polish Cities, 2020b; Institute of Urban and Regional Development, 2020). They are certainly a useful source of knowledge. Nevertheless, the author's goal is not to conduct a comprehensive reconstruction of the catalog of activities aimed at "fighting" the destructive effects of the COVID-19 pandemic. Such a task goes beyond the limited scope of this study. It is worth recalling that one talks about as many as sixty-six cities with poviat rights and the time limit reaching almost four months. The adoption of the aforementioned perspective results from the conviction that "giving a voice" to political actors has one fundamental value - it allows to capture the way in which the municipal self-government administration perceives and prioritizes the activities undertaken in the so-called crisis situation ${ }^{5}$ (see McKibbin, Fernando, 2020; Chakraborty, Maity, 2020; United Nations Procurement Division, 2020).

The situation related to the spread of the SARS-CoV-2 coronavirus raises at least two following questions:

(1) to what extent is the reaction of the municipal self-government administration to the COVID-19 pandemic a manifestation of "bottom-up" activities, and to what extent is it a part of the solutions adopted by the central government administration, i.e. "top-down" activities?

(2) do the implemented measures fit in a scheme of the response to the COVID-19 pandemic, replicated in subsequent cities, and if so, in what form does it manifest? In which areas of urban policy can this scheme be "captured"?

For the purposes of this paper, the following hypothesis is formulated: there is a reaction scheme and its implementation is a consequence of the "bottom-up" activities carried out in the areas of urban policy most affected by the COVID-19 pandemic of urban policy.

The author's goal is not to construct the analytical model about which Florina and Morton write. The aim is to capture the repetitive scheme of municipal administration activities undertaken in the face of the threat related to the spread of the SARS-CoV-2 coronavirus (see Florina, 1975; Morton, 1999, 2009). This reaction scheme is assumed

${ }^{4}$ As it will be mentioned in the article, the perspective of political actors should be understood in the discussed case through the prism of public policy (cf. Kraft, Furlog, 2021; Peters, 2019; Dunn, 2018; Sroka, 2018; Dye, 2017; Chandler, 2017; Zybała, 2013, 2012).

${ }^{5}$ It is difficult to disagree with the statement that the COVID-19 pandemic bears the features of a crisis situation, which is discussed in more detail in another author's study (see Glinka, 2020a). 
to be a derivative of at least three factors. The first factor is related to the similar nature of challenges (both typically health, economic and social ones) to which the surveyed municipalities must "respond." The second, is connected with the comparable organizational potential of these local governments - it is about cities with poviat rights which have a certain range of autonomy. Thirdly, it is about the "deficiencies" in the activities of the central government administration mentioned in the Introduction which are compensated by the municipal self-government administration through its activity.

The way of formulating the hypothesis requires the operationalization of the key terms and, consequently, the presentation of the conditions for its verification.

By "bottom-up" activities aimed at "fighting" the destructive consequences of the COVID-19 pandemic, the author means such activities that are not a "product" of the solutions adopted by the central government administration (laws, regulations, recommendations), but are independent initiatives of municipal self-government administration, i.e. local government authorities and their subordinate municipal offices and organizational units. One can talk about two types of activities: (1) carried out in the area of health (or rather its protection) and (2) reducing the economic and social effects of the COVID-19 pandemic. Moreover, it determines the presented approach to defining those activities which emphasize the importance of development activities aimed at meeting the collective needs of the members of the local government community. Therefore, it is an orientation typical of public policy and, characteristic of it, as it searches, diagnoses and solves the problems of a social nature ${ }^{6}$ (see: a footonote no. 4). Interesting insights on the activities of municipal self-government administration are provided by African cities fighting the Ebola virus (see Abramowitz et al., 2015; Laverack, 2015; Manoncurt, 2015; Coltart et al., 2017; Chia, Oyeniran, 2020). Nevertheless, taking into account the completely different political, economic and social realities, as well as the incomparable epidemiological threat, it is difficult to compare the functioning of Polish and African cities. For this reason, the author uses his own definition of "grassroots activities."

The implementation of public tasks in individual problem areas (sectoral) is an essence of the local government system shaped in Poland, regardless of whether it is at the local level (commune/city/city with poviat rights), poviat or voivodeship level. Apart from assessing the effectiveness and efficiency of its functioning, it can be tempted to say that it is a result, on the one hand, of the restitution of local government in 1990 (see Elander, Gustaffson, 1993; Regulski, 1993; Regulska, 1993, Regulski, Kocon, 1994; Regulska, Regulski, 2000) and, on the other hand, the challenges related to Poland's accession to the European Union and the related adaptation and preparatory activities (see Klimczuk-Kochańska, Klimczuk, 2006; Dąbrowski, 2012).

The area of urban policy can be seen, in this understanding, as a problem-defined (sector-specific) space of urban activity of local government which is to meet the needs and expectations of the local community (see: Holland, 2015).

Two research methods are used to verify the hypothesis: the analysis of the content of applicable legal acts (see Howland et al., 2006; Wesley, 2014) and the survey. ${ }^{7}$ The

${ }^{6}$ The briefly outlined way of understanding public policy is presented in detail in other works by the author, to which this part of the article refers (Glinka, 2020b, 2020d, p. 19, 2020e, pp. 67-68).

${ }^{7}$ As Newing and Fritsch (2009) argue, the survey questionnaire is a useful research tool used by the representatives of many scientific disciplines, including political scientists (cf. Brady 2000). Its useful- 
whole is supplemented with the elements of comparative analysis (Della Porta, 2008).

In the first step, the solutions adopted by the central government administration are presented. Namely, the assumptions of legal acts of various rank - not only laws and regulations (including the so-called anti-crisis shield), but also recommendations.

In the second step, the results of the mentioned survey are reported. In other words, the answers of the participants of this study (they were the employees of municipal offices authorized to provide public information on behalf of local government authorities) allow for the determination of two fundamental issues. First, it is about identifying those urban policy areas that are most affected (affected) by the COVID-19 pandemic. Secondly, it is necessary to emphasize the definition of such activities of municipal selfgovernment administration which can be treated as "bottom-up" activities, and the activities that, although carried out by the municipal self-government administration, fit in with the solutions adopted at the central level, namely "top-down" activities.

The survey was conducted between July and September 2020 (July, $1^{\text {st }}-$ September, $21^{\text {st }}$, 2020). Forty-seven cities took part in it. Therefore, the percentage of return was at the level of $71.2 \%$, which, bearing in mind the specific holiday period of the study, can be considered a satisfactory result. The sent out questionnaire consists of fifteen questions (closed ones: single and multiple choice) and open ones supplemented with a form. The article presents the answers obtained for the questions (namely two of them) that 'touch' the discussed issues. ${ }^{8}$

Positive hypothesis verification is subject to three conditions.

Firstly, the number of "bottom-up" activities indicated by the respondents must be greater than the number of "top-down" activities indicated.

Secondly, the respondents" indications for "bottom-up" activities must be at a sufficiently high level ( $90 \%$ or more), i.e. one that can also confirm a certain scheme (repeatability) of the response to the COVID-19 pandemic. $^{9}$

Third, "bottom-up" measures with a sufficiently high level of indications $(90 \%$ and more) must fit into those areas of urban policy that, according to respondents, are the most affected by the COVID-19 pandemic.

\section{Analysis}

Reaction of central government administration to the COVID-19 pandemic

The spread of the SARS-CoV-2 coronavirus and, related to it, the development of the epidemic situation in other EU Member States, forced the central government ad-

ness results from the possibility of collecting not only a series of data, but also obtaining an opinion 'at the source' in which the analyzed phenomena and processes take place. In this sense, the questionnaire allows for the collection of empirical material that could not be completed otherwise.

8 The remaining questions concerned such complex problems that they require a separate study. For example, the transnational and cross-border cooperation of municipal governments fits in the already mentioned concept of upscaling, and the cooperation of public, social and private actors - in the previously mentioned theory of the urban regime.

9 The $90 \%$ threshold is, obviously, arbitrary, although, as shown by the distribution of respondents' answers, it reflects the dominant responses. 
ministration to take measures aimed at "fighting" the destructive consequences of the COVID-19 pandemic. Statutory solutions played a key role. The relevant act, adopted on March 2, 2020, became the beginning of the entire legislative cycle, which consisted of the acts referred to as subsequent 'anti-crisis shields' (shield 1.0, shield 2.0, shield 3.0, shield 4.0, etc.).

Table 1 is an attempt to list the most important regulations that determined the activities of not only municipal self-government administration, but also private (entrepreneurs) and social actors (non-governmental organizations, informal groups of residents, individuals, etc.) operating in the city.

Table 1

Counteracting the destructive effects of the COVID-19 pandemic - the review of the most important assumptions of governmental regulations

\begin{tabular}{|c|c|c|}
\hline \multicolumn{2}{|r|}{ Council of Ministers } & \multirow{2}{*}{$\begin{array}{c}\text { Listed by } \\
\text { respondents } \\
\text { (see Graph 2) }\end{array}$} \\
\hline Legal act & Main assumptions & \\
\hline $\begin{array}{l}\text { Law, } \\
\text { 2nd March } \\
2020\end{array}$ & $\begin{array}{l}\text { - Possibility of issuing orders to local government bodies, local government } \\
\text { legal persons and local government organizational units by the voivode } \\
\text { - Possibility of granting targeted subsidies to local government units from the } \\
\text { state budget } \\
\text { - Providing employees with personal protective equipment; the obligation to } \\
\text { inform employees about the risks associated with COVID-19; the ability to } \\
\text { change the mode of work by employees }\end{array}$ & $\mathrm{A} 1, \mathrm{~A} 3, \mathrm{~A} 15$ \\
\hline $\begin{array}{l}\text { Law, } \\
31 \text { st March } \\
2020 \\
\text { 'shiled 1.0' }\end{array}$ & $\begin{array}{l}\text { - Possibility to change: } \\
\text { - plan of income and expenditure of the budget of a local government } \\
\text { unit, } \\
\text { - long-term financial forecast, } \\
\text { - allocation of the special-purpose reserve created in the budget of the local } \\
\text { government unit without obtaining the opinion of the committee respon- } \\
\text { sible for the budget of the decision-making body, } \\
\text { - limit of liabilities due to contracted credits and loans and issued securi- } \\
\text { ties. } \\
\text { - Possibility to create a new special-purpose reserve without the need to ob- } \\
\text { tain the opinion of the committee responsible for the budget of the decision- } \\
\text { making body } \\
\text { - Possibility of conducting deliberations of organs using means of distance } \\
\text { communication or by correspondence (remote deliberation mode) } \\
- \text { Possibility of resigning from obtaining receivables by local government unit } \\
\text { or its organizational units (e.g. in the field of lease, tenancy, use) } \\
\text { - Possibility of introducing a relief or spreading into installments civil law } \\
\text { receivables due to a local government unit or its organizational units } \\
\text { - Possibility of granting a subsidy to a budgetary enterprise that carries out } \\
\text { tasks related to counteracting COVID-19 (from the budget of a local govern- } \\
\text { ment unit) exceeding } 50 \% \text { of its operating costs }\end{array}$ & A27 \\
\hline $\begin{array}{l}\text { Law, } \\
16 \text { th April } \\
2020 \\
\text { 'shield 2.0' }\end{array}$ & $\begin{array}{l}\text { - Possibility to transfer a local government employee to perform another job } \\
\text { in an organizational unit of social assistance }\end{array}$ & - \\
\hline $\begin{array}{l}\text { Law, } \\
\text { 14th May } \\
2020 \\
\text { 'shield 3.0' }\end{array}$ & $\begin{array}{l}\text { - Extending the deadline for submitting a report on the condition of a local } \\
\text { government unit by } 60 \text { days }\end{array}$ & $\mathrm{A} 30$ \\
\hline
\end{tabular}




\begin{tabular}{|c|c|c|}
\hline $\begin{array}{l}\text { Law, } \\
19 \text { th June } \\
2020 \\
\text { 'shield 4.0' }\end{array}$ & $\begin{array}{l}\text { - Possibility to reduce the fee and not to collect rent and lease. } \\
\text { - Changing the budget may involve exceeding the ratio referred to in Art. } 242 \\
\text { of the Act of August 27, } 2009 \text { on Public Finance. }\end{array}$ & $\begin{array}{l}\text { A } 19, \text { A } 22, \\
\text { A23, A24, } \\
\text { A25, A26 }\end{array}$ \\
\hline $\begin{array}{l}\text { Regulation } \\
31 \text { st March } \\
2020\end{array}$ & $\begin{array}{l}\text { - Mandatory quarantine. } \\
\text { - Restrictions on crossing the border of the Republic of Poland. } \\
\text { - Ban on movement, with exceptions. } \\
\text { - Limiting the activities of catering, cultural, entertainment, tourist, accom- } \\
\text { modation, sports, cosmetic, etc. entities } \\
\text { - Possibility of introducing restrictions in the performance of tasks by the pub- } \\
\text { lic administration office } \\
\text { - Ban on the organization of shows and gatherings of people } \\
\text { - Order to make available real estate, premises and areas included in the anti- } \\
\text { epidemic plans } \\
\text { - Limiting the use of green areas } \\
\text { - Introduction of an order to provide real estate, premises and land } \\
\text { - Obligation to keep social distance ( } 2 \text { meters) } \\
\text { - Limiting the number of passengers on public collective transport to half of } \\
\text { the seats }\end{array}$ & $\begin{array}{c}\text { A14, A16, } \\
\text { A17 }\end{array}$ \\
\hline $\begin{array}{l}\text { Regulation } \\
19 \text { th April } \\
2020\end{array}$ & $\begin{array}{l}\text { - Mandatory cavarantine. } \\
\text { - Restrictions on crossing the border of the Republic of Poland. } \\
\text { - Ban on movement, with exceptions } \\
\text { - Limiting the activities of catering, cultural, entertainment, tourist, accom- } \\
\text { modation, sports, cosmetic, etc. entities } \\
\text { - Possibility of introducing restrictions in the performance of tasks by the pub- } \\
\text { lic administration office } \\
\text { - Ban on the organization of shows and gatherings of people } \\
\text { - Order to provide real estate, premises and areas included in the anti-epidem- } \\
\text { ic plans } \\
\text { - Limiting the use of green areas } \\
\text { - Order to keep social distance ( } 2 \text { meters) } \\
\text { - Reduction of the number of passengers of public collective transport to half } \\
\text { of the seats } \\
\text { - Obligation to cover the mouth and nose in public transport and public places }\end{array}$ & $\begin{array}{c}\text { A14, A16, } \\
\text { A17 }\end{array}$ \\
\hline \multicolumn{3}{|c|}{ Minister of Health } \\
\hline $\begin{array}{l}\text { Regulation } \\
\text { 20th March } \\
2020\end{array}$ & $\begin{array}{l}\text { - Limiting the activities of catering, cultural, entertainment, tourist, accom- } \\
\text { modation, sports, cosmetic, etc. entities } \\
\text { - Possibility of introducing restrictions in the performance of tasks by the pub- } \\
\text { lic administration office } \\
\text { - Ban on the organization of shows and gatherings of people } \\
\text { - Order to provide real estate, premises and areas included in the anti-epidem- } \\
\text { ic plans }\end{array}$ & A14 \\
\hline $\begin{array}{l}\text { Regulation } \\
\text { 24th March } \\
2020\end{array}$ & $\begin{array}{l}\text { - Ban on movement, with exceptions } \\
\text { - Order to keep social distance (1.5 meters) } \\
\text { - Reduction of the number of passengers of public collective transport to half } \\
\text { of the seats }\end{array}$ & A16, A17 \\
\hline \multicolumn{3}{|c|}{ Chief Sanitary Inspectorate } \\
\hline $\begin{array}{l}\text { Recommen- } \\
\text { dations, } \\
\text { March, } \\
\text { April, May } \\
2020\end{array}$ & $\begin{array}{l}\text { - Carrying out tests for the presence of SARS-CoV-2 coronavirus } \\
\text { - Keeping social distancing and avoiding gatherings } \\
\text { - Compliance with hygiene rules } \\
\text { - Special mode of functioning of kindergartens, childcare institutions and } \\
\text { schools }\end{array}$ & - \\
\hline
\end{tabular}

Source: Author's compilation on the basis of Act, 2020a, 2020b, 2020c, 2020d, 2020e; Regulation, 2020a, 2020b, 2020c, 2020d; Recommendations, 2020. 
Table 1 takes into account the key changes of the 'anti-crisis shield' made during the so-called first wave of the COVID-19 pandemic. What is more, it also presents the assumptions of selected ordinances of the Council of Ministers, ordinances of the Minister of Health and recommendations of the Chief Sanitary Inspectorate which were in force in the same period, i.e. between March 2020 and June 2020.

As Table 1 shows, the first group of regulations - the regulations "affecting" the functioning of municipal self-government administration - should be analyzed from two perspectives. On the one hand, attention is drawn to the concern to maintain the financial stability of the local government sector, as evidenced by the possibility of obtaining subsidies from the state budget. On the other hand, the option of reducing the burdens imposed on by municipal governments on the actors operating in their area, primarily private actors, should be emphasized. The possibility of introducing discounts or spreading payments into installments may be an example of such activities. The second group of regulations consists of such provisions that affect the activity of private and social actors. In this case, one talks about numerous, often severe limitations, including running a business, traveling, or gathering.

It should be noted that Table 1 does not present the assumptions of all the regulations that determine the activities of municipal self-government administration in the period between March and June 2020. For example, informing about the COVID-19 pandemic, ensuring cleanliness of public places and public utilities, or caring for people with disabilities result from such statutory solutions that were in force long before March 2020 (Act 2001, Act 1998a). However, during the so-called first wave of the COVID-19 pandemic, they seem to have acquired special significance. Moreover, Table 1 summarizes, on the one hand, the assumptions of the analyzed documents, and, on the other, the indications of the participants of the survey. It turns out to be important because only fourteen indications are included in the regulations of the central government administration (cf. Graph 2). This issue will be discussed later.

\section{Reaction of the municipal self-government administration to the COVID-19 pandemic}

The reflection on the reaction of the municipal self-government administration must be preceded by the diagnosis of urban policy areas that are exposed to the destructive consequences of the COVID-19 pandemic. Figure 1 illustrates the distribution of votes by twenty-two sector (problem) areas, ranging from spatial order and real estate management (UP1) to cooperation with local and regional communities of other countries (UP22). ${ }^{10}$ The distinction between the twenty-two areas is not accidental. It corresponds to the tasks of communes (cities) defined in the aforementioned Act of March 8, 1990 on

${ }^{10}$ The participants of the study had the opportunity to identify any number of urban policy areas which, in their opinion, were affected by the destructive effects of the COVID-19 pandemic during the so-called first wave (March 2020-June 2020). The question therefore concerned the assessment of the effects of the COVID-19 pandemic already felt in spring 2020, in the form of an indication of "yes" or "no." However, the author of the article did not formulate a request for a gradation of the negative impact of the COVID-19 pandemic on the functioning of the individual areas of urban policy. 
the local government, ${ }^{11}$ which, in contrast to the National Urban Policy (NUP), forms the proper foundation for the functioning of the analyzed cities. ${ }^{12}$

\section{Graph 1. Urban policy areas exposed to the devastating effects of the COVID-19 pandemic according to the surveyed municipal self-government administration}

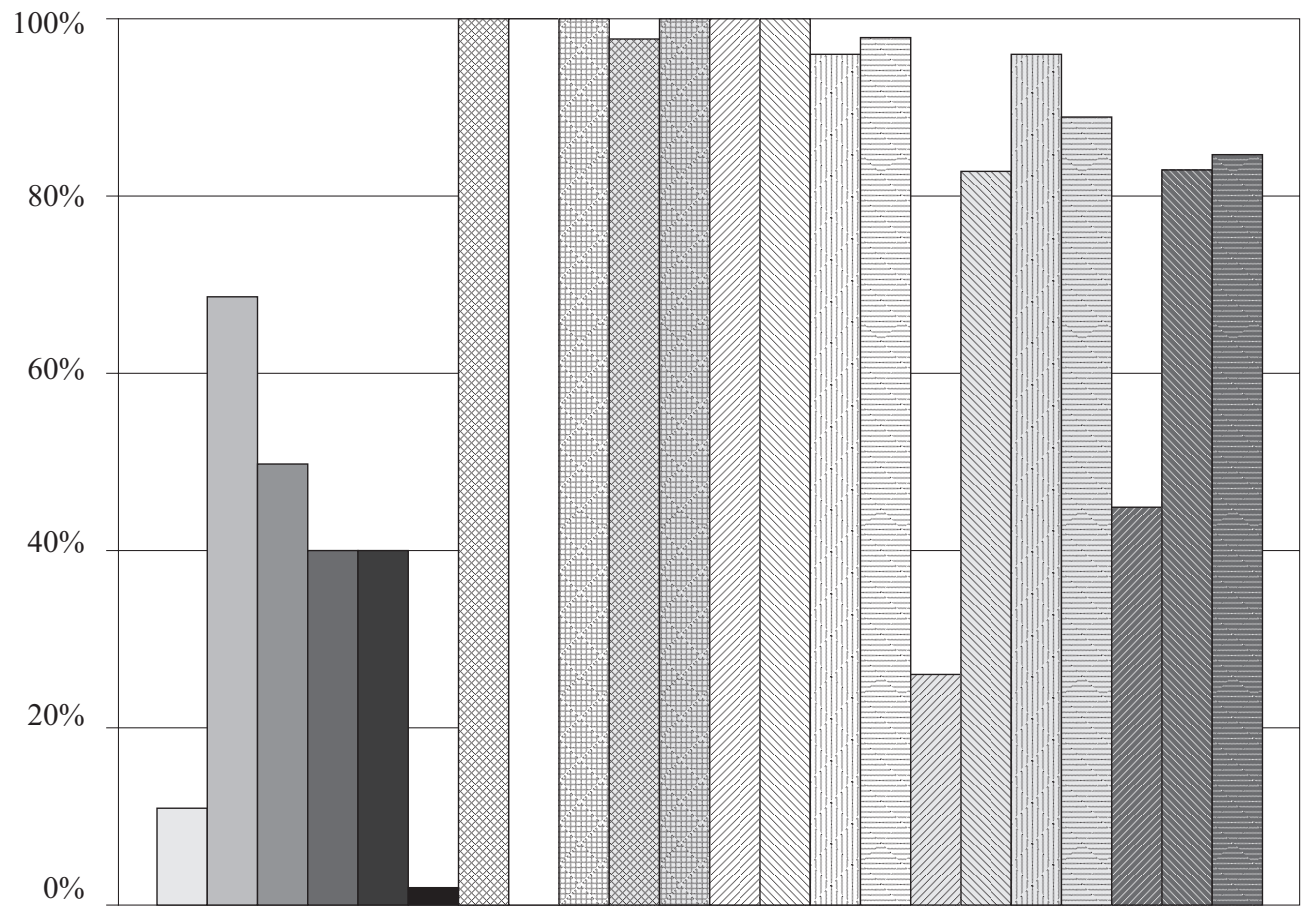

Urban policy area (UP)

UP1 Spatial order and real estate management; $\square$ UP2 Environment and nature protection, water management; UP3 Roads and road traffic organization; \UP4 Water supply, municipal sewage treatment; $\square$ UP5 Landfills and garbage collection; $\square$ UP6 Electricity and gas supply; UP7 Local public transport; $\square$ UP8 Health care;

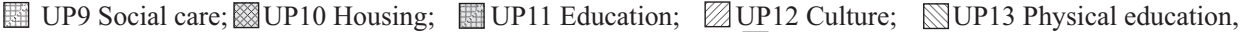
tourism, recreation; UUP14 Trade; ZUP15 Labour market; $\triangle$ UP16 Cementaries; $\square$ UP17 Order and public

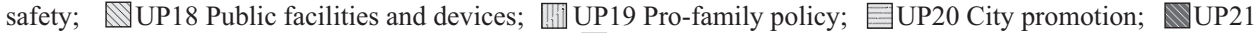
Cooperation with non-governmental organizations; ${ }^{-}$UP22 Cooperation with local and regional communities of other countries

Source: Author's compilation on the basis of the survey conducted in the period July 2020-September 2020.

The areas negatively affected by the COVID-19 pandemic include: local public transport (UP7, 100\%), health care (UP8, 100\%), social care (UP9, 100\%), education (UP11, $100 \%$ ), culture (UP12, 100\%), psysical education, tourism, recreation (UP13, 100\%). Next, the limitations relating to: housing (UP10, 98\%), labour market (UP15, 98\%), trade (UP14, 96\%), public facilities and devices (UP18, 96\%). On the other hand, the

11 These tasks are listed in Art. 7.1. of the Act of March 8, 1990 on local self-government (see Act, 1990).

${ }^{12}$ A slightly different catalog of tasks is presented in the Act of 5 June 1998 on poviat self-government (see Act, 1998). 
negative consequences of the COVID-19 pandemic 'affect' to the least extent such areas as: electricity and gas supply (UP6, 2\%), spatial order and real estate management (UP1, $10 \%$ ), cementary functioning (UP16, 26\%).

The analysis of respondents' indications seems to justify the conclusion that the destructive impact of the COVID-19 pandemic is manifested in areas related to the provision of key, in a sense, fundamental public services, the essence of which are interpersonal interactions. It is a predictable conclusion as the main goal of the introduced lockdown is to slow down the dynamics of these contacts. In this sense, the destructive consequences of the COVID-19 pandemic seem to be derived from the restrictions implemented.

Graph 2 presents the activities of municipal self-government administration aimed at 'fighting' the negative consequences of the COVID-19 pandemic. ${ }^{13}$ Thirty variants of responses to these consequences were analyzed, ranging from reporting on COVID-19 pandemic (A1) to suspensions in time limits in administrative proceedings (A30). The scope of the implemented 'protective' measures is therefore very wide and varied. Despite this, the analysis of the answers provided by the employees of municipal offices in forty-seven cities with poviat rights allows for the identification of specific trends. ${ }^{14}$

It should be emphasized that the respondents' answers are "incomplete" in the sense that they do not apply to all the solutions of the central government administration aimed at "fighting" the COVID-19 pandemic, mentioned in the earlier part of the article (cf. Table 1). Therefore, it can be assumed (very cautiously) that the fact of "omitting" some "top-down" solutions speaks for their relatively low importance for the functioning of the examined cities, obviously, in the opinion of the participants of the study. Moreover, the discrepancy between the respondents' indications and the regulations of the central government administration may also suggest that these indications refer rather to the activity of private and social entities than to the activities of the municipal self-government administration itself.

First of all, it is worth paying attention to the activities related to 'direct' as well as 'indirect' health protection against the SARS-CoV-2 coronavirus (the blue color in Graph 2). It turns out that practically every examined city perceives the importance of initiatives such as: informing about COVID-19 pandemic (A1, 100\%), providing em-

13 The participants of the study could indicate any number of activities aimed at "fighting" the destructive consequences of the COVID-19 pandemic that were undertaken (implemented) during the so-called first wave (March 2020-June 2020). Moreover, the respondents could extend the list of activities sent to them with their own positions. As a result, the presented catalog of activities is very broad. It should be emphasized that not all of the mentioned activities are completely new, i.e. not carried out before. For example, the choice of the option "introduction of electronic document flow at the office" does not mean that the office did not use such a document flow mode prior to the COVID-19 pandemic. However, this option indicates a change noticed by the respondents in this respect, i.e. an increase in the intensity and/or scale of electronic running.

${ }^{14}$ The literature on the subject provides at least several other variants of classifying the activities of municipal self-government administration. For example, interesting considerations on the strategies implemented by Brazilian cities are presented by Nobuiuki Costa Ito and his team of associates. Researchers distinguish three main paths - 'plural collaboration,' 'public action' and 'resource-based path' (see Ito et al., 2020). 


\section{Graph 2. Counteracting the destructive effects of the COVID-19 pandemic - "bottom-up' actions versus "top-down" actions according to the surveyed municipal self-government adminsitration}

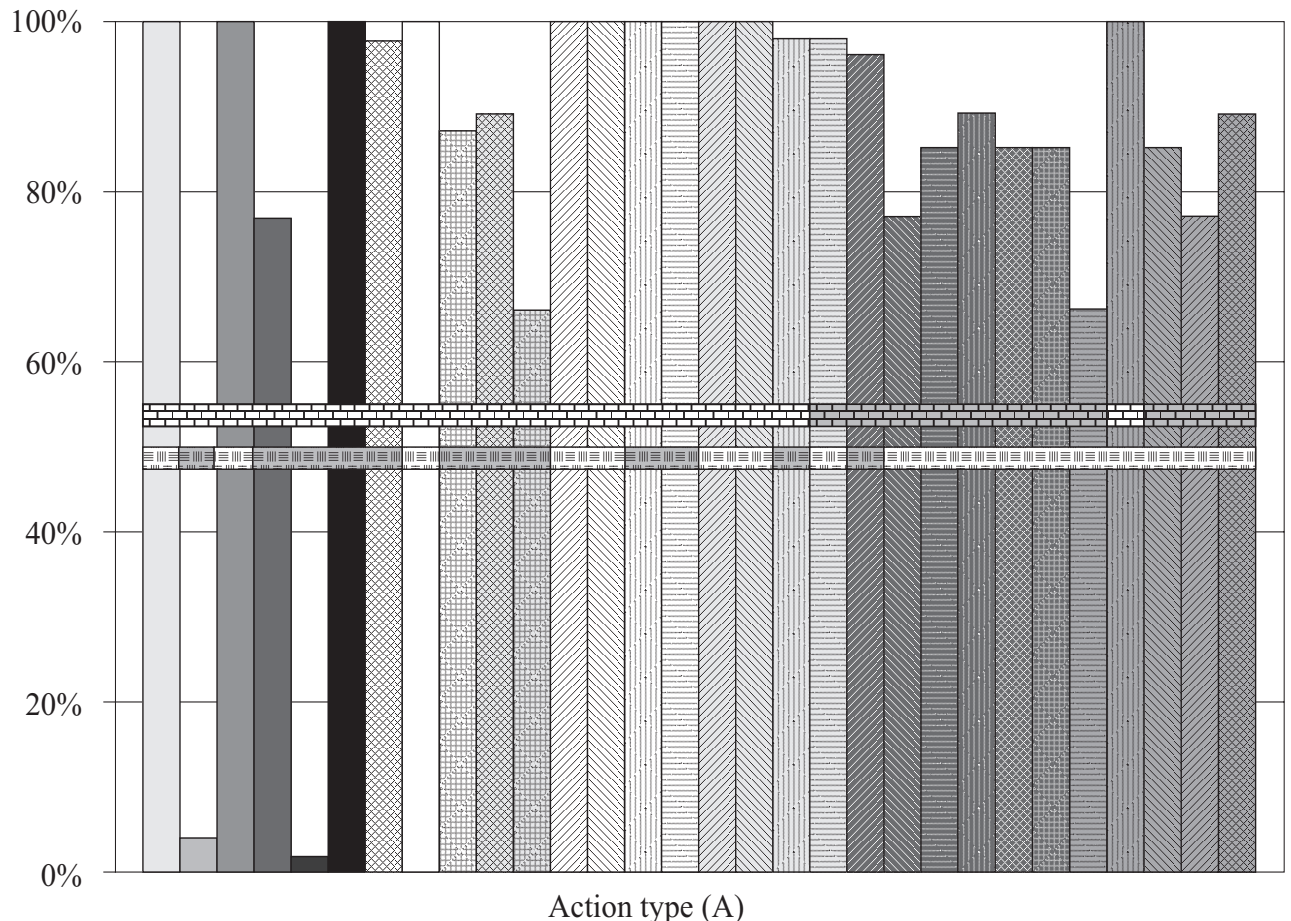

$\square$ A1 Reporting on the COVID-19 pandemic; $\square$ A2 Providing municipal office employees with SARS-CoV-2;

A3 Providing employees of the municipal office with personal protective equipment;

A4 Providing employees of the municipal office with free psychological/pedagogical assistance; $\square$ A5 Providing city residents with tests for the presence of SARS-CoV-2 coronavirus; A6 Providing city residents with personal protective equipment; A7 Providing city residents with free psychological/pedagogical assistance; $\square$ A8 Providing ongoing support/care for the elderly and disabled (purchase and delivery service of medicines, food, etc.);

闻 A9 Providing clients of the municipal office with personal protective equipment; A10 Providing hospitals/ health centers with personal protective equipment; A11 Handing over medical equipment to hospitals/health centers; 12 Disinfection of public utility facilities (offices, schools, libraries, etc.); A13 Disinfection of public utility (poles/notice boards, bus shelters, etc.); D14 Introduction of electronic document circulation in the municipal office; $\quad$ A15 Informing residents about the possibility of settling matters in the office via the Internet; A16 Changing the rules of using local public transport (introducing a passenger limit, etc.); $\mathbb{A}$ A17 Change of the local public transport timetable; $\quad$ A18 Turn off the traffic signal buttons (in front of pedestrian crossings); A19 Suspension/reduction of the parking fee collection; $\square$ A20 Purchase/rental of computer equipment used by students/teachers in the course of distance learning; A21 Purchase/rental of an ambulance enabling mobile collection of material for testing for the presence of SARS-CoV-2 coronavirus; A22 Suspension/reduction of collecting tax on means of transport; A23 Property tax suspension/reduction; A24 Suspension/reduction of the market fee collection; 125 Suspension/reduction of charging the advertising fee; A26 Suspension/ reduction of the collection of fees for waste collection for entrepreneurs; 1027 Change of the operating mode of local government authorities (introduction of a remote form); $\triangle \mathrm{A} 28$ The possibility of replacing the mayor of the city by his deputy; $\quad$ A29 Guarantee of the office's continuity, granted by the voivode; A30 Suspension of time limits in administrative proceedings

臣 - the activities of a health nature; 臣 - the activities of an economic and social nature;

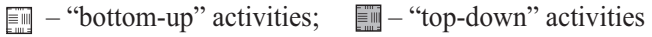

Source: Author's compilation on the basis of the survey conducted in the period July 2020-September 2020. 
ployees of the municipal office with presonal protective equipment (A3,100\%), providing city residents with presonal protective equipment $(\mathrm{A} 6,100 \%)$, providing the ongoing support/care (A8, 100\%), disinfection of public utility facilities (A12, 100\%), disinfection of public utilities (A13,100\%), introducting of electronic document circulation (A14, 100\%), informing residents about the possibility of contact with office via Internet (A15, 100\%), changing the rulet of using local transport system (A16, 100\%), change the local public transport timetable (A17, 100\%), change of the operation mode of local authorities (A27, 100\%).

The relatively low percentage of responses indicating the practice of testing for the presence of SARS-CoV-2 coronavirus, both among municipal office employees (A2, $4 \%$ ) and city residents (A5, 2\%), should be considered symptomatic. Without ultimately determining the reasons for the low 'popularity' of such activities, one may be tempted to say that the limited financial and organizational resources of Polish cities, treated as a sine qua non condition for implementing a certain testing standard, play an important role.

The second group consists of the activities not directly related to health security (the yellow color in Graph 2), although very important for economic and social reasons. In this case, one talks about the suspension/reduction of: parking fee (A19, $98 \%$ ), tax on means of transport (A22, 85\%), market fee (A24, 85\%), advertising fee (A25, 85\%).

Attention is drawn to the predominance of the measures aimed at health protection (nineteen measures marked in blue in Graph 2) compared to the measures affecting the economic and social sphere (eleven measures marked in yellow in Graph 2).

Taking into account the main goal of these considerations, the key role is played by the distinction between those activities that are a manifestation of the initiative of municipal governments (red color in Graph 2) and those that fit into the solutions adopted by the central government administration (green color in Graph 2).

It turns out that "top-down" activities (eighteen), such as changing the public transport timetables (A17) or introducing reductions in property tax (A23), prevail. Among the "bottom-up" activities (twelve), it is necessary to mention the provision of personal protective equipment to city residents (A6), or the provision of such equipment to hospitals (A10)..$^{15}$

It is worth noting that in each of these two groups, one can list the activities that were chosen the most frequently.

Thus, indications at the level of $90 \%$ and higher accompanied, in the case of "topdown" measures, such measures as: informing about COVID-19 pandemic (A1, 100\%), providing of personal protective equipment to municipal office employess (A3, 100\%), providing the ongoing support/care (A8, 100\%), disinfection of public utility facilities (A12, 100\%), disinfection of public utilities (A13, 100\%), changing the rulet of using local transport system (A16, 100\%) changing the local public transport timetable (A17,

${ }^{15}$ It should be noted that some of the activities - for example, testing for the presence of the SARS-CoV-2 coronavirus - are included in the catalog of tasks financed by the central government administration. There are, however, situations in which municipalities independently (from their own resources) carried out testing actions. The question of the survey concerned precisely such "oversized" activities of municipal self-government administration. 
$100 \%$ ), changing of the operation mode of local authorities (A27, 100\%), suspension/ reduction of parking fee (A19, 98\%).

However, in the case of "bottom-up" activities, these were: providing city residents with presonal protective equipment (A6, 100\%), introducting of electronic document circulation (A14, 100\%), informing residents about the possibility of contact with office via Internet $(\mathrm{A} 15,100 \%)$, providing residents with free psychological/pedagocical assistance (A7, 98\%), turning of the traffic signal buttons (A18, 98\%), purchasing the computer equipment used by teachers or students (A20, 96\%).

\section{Discussion and conculsion}

The spread of the SARS-CoV-2 coronavirus is, according to the opinions formulated not only by epidemiologists, but also economists, political scientists, sociologists and lawyers, one of the greatest development challenges faced by the modern state. As it has been proven, cities, including municipal self-government administration, which make an effort to counteract the negative processes and phenomena 'affecting' many problem areas (sectors) also contribute to the response to the COVID-19 pandemic.

Therefore, the conducted analysis does not allow to confirm the hypothesis (see Table 2).

Firstly, it turns out that the catalog of activities aimed at counteracting the destructive effects of the COVID-19 pandemic is dominated by "top-down" activities and not, as originally assumed, by "bottom-up" activities (eighteen "top-down" activities versus twelve "bottom-up" activities).

Secondly, it turns out that the activities of municipal self-government administration do constitute a reaction scheme to the COVID-19 pandemic (indications at the level $90 \%$ and higher), but its core is formed by both the "top-down" initiatives (nine: A1, A3, A8, A12, A13, A16, A17, A27, A19), as well as the "bottom-up" initiatives (six: A6, A14, A15, A7, A18, A20).

Thirdly, the difficulties associated with a positive verification of the hypothesis are also indicated by the cross-reference, on the one hand, of those areas of urban policy that were most "affected" by the destructive consequences of the COVID-19 pandemic and the activities taken by the municipal self-government administration. It turns out that these areas are dominated by the activities resulting from "top-down" regulations. One talks bout UP7 (local public transport), UP8 (health care), UP (social care) and UP18 (public facilities and devices) as well as A16, A17, A19, A3, A8, A12 and A13 (see Table 2).

Bearing in mind the above, one can formulate at least three basic conclusions. However, it should be remembered that the adopted research perspective, namely the perspective of political actors, makes us treat the presented results with some caution. This is because one talks about the opinions and observations formulated by the respondents.

Firstly, counteracting the destructive consequences of the COVID-19 pandemic is a difficult task that requires the involvement of appropriate organizational and financial resources. In this sense, it naturally forces the activity of state bodies and institutions whose capabilities to "fight" the SARS-CoV-2 coronavirus are incomparably 
greater than those of municipal governments. As has been proven, municipal self-government administrations obviously undertake various activities aimed at "fighting" the COVID-19 pandemic. However, they are not able to operate effectively and efficiently in every area of urban policy. In this sense, the involvement of the central level seems not only desirable but also indispensable. This is confirmed by the indications of the respondents (eighteen "top-down" actions versus twelve "bottom-up" actions).

Table 2

Reaction to the COVID-19 pandemic - the summary of the analysis on the basis of the contucted survey

\begin{tabular}{|c|c|c|c|c|}
\hline & Reaction & \multicolumn{3}{|c|}{$\begin{array}{c}\text { Main manifestiations of reaction } \\
\text { (above } 90 \% \text { ) }\end{array}$} \\
\hline & $\begin{array}{l}\text { "Top-down" } \\
\text { (18 types of activities) }\end{array}$ & \multicolumn{3}{|c|}{$\begin{array}{l}9 \text { activities: } \\
\text { 100\%: } \mathrm{A} 1, \mathrm{~A} 3, \mathrm{~A} 8, \mathrm{~A} 12, \mathrm{~A} 13, \mathrm{~A} 16, \mathrm{~A} 17, \mathrm{~A} 27 \\
98 \%: \mathrm{A} 19\end{array}$} \\
\hline & $\begin{array}{l}\text { "Bottom-up" } \\
\text { (12 types of activities) }\end{array}$ & \multicolumn{3}{|c|}{$\begin{array}{l}6 \text { activities: } \\
\text { 100\%: } \mathrm{A} 6, \mathrm{~A} 14, \mathrm{~A} 15 \\
98 \%: \mathrm{A} 7, \mathrm{~A} 18 \\
96 \%: \mathrm{A} 20\end{array}$} \\
\hline : & $\begin{array}{l}\text { Urban policy areas } \\
\text { and activities }\end{array}$ & $\begin{array}{l}\text { Urban policy areas: } \\
\text { 100\%: } \\
\text { UP7 (local public transport) } \\
\text { UP8 (health care) } \\
\text { UP9 (social care) } \\
\text { UP11 (education) } \\
\text { UP12 (culture) } \\
\text { UP13 (physical education, tourism) } \\
\text { 98\%: } \\
\text { UP10 (housing) } \\
\text { UP15 (labour market) } \\
\text { 96\%: } \\
\text { UP14 (trade) } \\
\text { UP18 (public facilities and devices) }\end{array}$ & $\begin{array}{l}\text { "Top-down" } \\
\text { activities } \\
\text { A16, A17, A19 } \\
\text { A3 } \\
\text { A8 }\end{array}$ & $\begin{array}{l}\text { "Botton-up" } \\
\text { activities } \\
\text { A18 } \\
\text { A6, A7 } \\
\text { A20 }\end{array}$ \\
\hline
\end{tabular}

Source: Autor's own compilation.

Secondly, the involvement of central government administration raises the question of the limits of local autonomy. In this case, one talks about the decision-making and organizational autonomy, widely commented on in the literature, which local governments, including municipal governments, are equipped with. Although, as mentioned, Polish local government should be classified in the category of those local governments that are characterized by a relatively high level of autonomy, some doubts may arise from the recentralization trends observed in recent years (see Rajca, 2019).

Thirdly, a reflection dedicated to the methods of 'fighting' the COVID-19 pandemic opens up new, no less important and therefore interesting research fields. In the first case, it is worth formulating a question about the effectiveness of the activities carried out, especially taking into account the needs and expectations of residents formulated with regard to the quality of public services (which, due to the objective conditions of the pandemic period, generally declines). It seems equally valuable to adopt a longitudinal perspective that would allow the monitoring of the entire sequence of activi- 
ties undertaken by the municipal self-government administration. The extension of the study's caesura seems to be all the more desirable and justified as the development of the COVID-19 pandemic is not limited to the aforementioned 'first wave', but also settles on the transmission of the SARS-CoV-2 coronavirus over time. In this sense, taking into account the two reported research niches may indicate the direction of further, in-depth analyzes dedicated to the functioning of the city and its inhabitants in the conditions of a crisis situation. It is worth emphasizing once again that the successive waves of the COVID-19 pandemic reflect the full spectrum of activities undertaken by municipal selfgovernment administrations.

\section{Bibliography}

Abramowitz S. M. et al. (2015), Community-Centered Responses to Ebola in Urban Liberia: The View from Below, "PLOS Neglected Tropical Diseases", 9(5).

Act. (1990), Journal of Laws 1990, no. 16, item. 95. Act of March 8, 1990 on local government.

Act. (1998a), Journal of Laws 1998, no. 91, item. 578. Act of June 5, 1998 on poviat self-government.

Act. (1998b), Journal of Laws 1998, no. 9, item. 576. Act of June 5, 1998 on voivodship self-government.

Act. (2001), Journal of Laws 2001, no. 112, item 1198, Act of September 6, 2001 on access to public information.

Act. (2018), Journal of Laws 2018, item 130, 1349. Act of 11 January 2018 amending certain acts in order to increase the participation of citizens in the process of selecting, functioning and controlling certain public bodies.

Act. (2020a), Journal of Laws 2020, item. 374, The Act of March 2, 2020 on special solutions related to the prevention, prevention and combating of COVID-19, other infectious diseases and crisis situations caused by them.

Act. (2020b), Journal of Laws 2020, item. 567, The Act of March 31, 2020 amending the Act on special solutions related to the prevention, prevention and combating of COVID-19, other infectious diseases and crisis situations caused by them, and certain other acts.

Act. (2020c), Journal of Laws 2020, item. 695, Act of April 16, 2020 on specific support instruments in connection with the spread of SARS-CoV-2 virus.

Act. (2020d), Journal of Laws 2020, item. 875, Act of May 14, 2020 amending certain acts in the field of protective measures in connection with the spread of SARS-CoV-2 virus.

Act. (2020e), Journal of Laws 2020, item. 1086, Act of 19 June 2020 on interest subsidies for bank loans granted to entrepreneurs affected by the effects of COVID-19 and on simplified proceedings for approval of an arrangement in connection with the occurrence of COVID-19.

Association of Polish Cities (2020a), Stanowisko Zarzadu ZMP w sprawie stanu epidemii CoVID-19, https://www.miasta.pl/aktualnosci/stanowisko-zarzadu-zmp-w-sprawie-stanu-epidemii-covid-19, 10.11.2020.

Association of Polish Cities (2020b), Miasta wobec pandemii, https://www.miasta.pl/kategorie-aktualnosci/miasta-wobec-epidemii, 10.02.2021.

Awasthi A., Mavlankar D. (2020), COVID-19 in India: an epidemic in congested cities. BMJ Global Health, https://blogs.bmj.com/bmjgh/2020/05/28/covid-19-in-india-an-epidemic-in-congested-cities/, 10.11.2020.

Bartolini S. (2005), Restructuring Europe. Centre Formation, System Building, and Political Structuring between the Nation State and the European Union, Oxford University Press, Oxford. 
Brady H. E. (2000), Contributions of Survey Research to Political Science, "Political Science and Politics", 33(1).

Brenner N. (1998), Global cities, global states: global city formation and state territorial restructuring in contemporary Europe, "Review of International Political Economy", 5(1).

Brenner N. (2001), The limits to scale? Methodological reflections on scalar structuration, "Progress in Human Geography", 25(1).

Brenner N. (2003), Standortpolitik. State Rescaling and the Metropolitan Governance in Western Europe, "disP - The Planning Review", 152.

Brenner N. (2004), New State Spaces. Urban Governance and the Rescaling of Statehood, Oxford University Press, New York.

Brenner N. (2019), New Urban Spaces. Urban Theory and the Scale Question, Oxford University Press, New York.

Chakraborty I., Maity P. (2020), COVID-19 outbreak: Migration, effects on society, global environment and prevention, "Science of the Total Environment", 728(1).

Chandler J. A. (2017), Public policy and private interest. Ideas, self-interest and ethics in public policy, Routledge, Taylor \& Francis Group, London-New York.

Chia T., Oyeniran O. I. (2020), Human health versus human rights: An emerging ethical dilemma arising from coronavirus disease pandemic, "Ethics Med Public Health", Jul. Sep.

Coltart C. E. M. et al. (2017), The Ebola outbreak, 2013-2016: old lessons for new epidemics, "Philos Trans R Soc Lond B Biol Sci", May.

Dąbrowski M. (2012), Shallow or deep Europeanisation? The uneven impact of EU Cohesion policy on the regional and local authorities in Poland, "Environment and Planning C Government and Policy", 30(4).

Della Porta D. (2008), Comparative analysis: case-oriented versus variable-oriented research, in: Approaches and Methodologies in the Social Sciences. A Pluralist Perspective, eds. D. Della Porta, M. Keating, Cambridge University Press, Cambridge.

DiGaetano A., Klemanski J. S. (1993), Urban regimes in comparative perspective. The politics of urban development in Britain, "Urban Affairs Quarterly", 29.

Dunn W. N. (2018), Public policy analysis. An integrated approach, Routledge, New York-London.

Dye T. R. (2017), Understanding public policy, Pearson, Boston.

Easton D. (1965a), A System Analysis of Political Life, Wiley, New York.

Easton D. (1965b), A Framework for Political Analysis. Englewood Cliffs, Prentice Hall, New York.

Elander I., Gustaffson M. (1993), The re-emergence of local self-government in Central Europe. Some notes on the first experience, "European Journal of Political Research", 23(3).

Elkin S. L. (1987), City and Regime in the American Republic, University of Chicago Press, Chicago.

EUROCITIES (2020), Live updateds COVID-19, https://covidnews.eurocities.eu/city-overview-ofmeasures/, 10.02.2021.

European Committee of the Regions (2020), Potential impacts of COVID-19 on regions and cities of the EU, https://cor.europa.eu/en/engage/studies/Documents/IMPACTS-COVID-19.pdf, 10.02.2021.

Florina M. P. (1975), Formal Models in Political Science, “American Political Science Journal”, 19(1).

Glaeser E. (2011), Triumph of the City. How our Greatest Invention Makes Us Richer, Smarter, Greener, Healthier and Happier, Penguin Books, New York.

Glinka K. (2015), Cooperation within Network? City marketing in the network perspective, in: New Public Governance in the Visegrad Group (V4), ed. R. Wiszniowski, K. Glinka, Wydawnictwo Adam Marszałek, Torun.

Glinka K. (2020a), E-komunikowanie polityczne w warunkach pandemii COVID-19 - doświadczenia małych miast województwa dolnośląskiego, "Polityka i Społeczeństwo", 4(18). 
Glinka K. (2020b), Polityka miejska w marketingu prezydentów największych miast Dolnego Śląska, Wydawnictwo Adam Marszałek, Toruń.

Glinka K. (2020c), The urban regime theory in political science research - the possibilities and limitations of implementation, "Polish Political Science Review. Polski Przegląd Politologiczny", $8(2)$.

Glinka K. (2020d), System conditions of urban policy in Poland and Hungary, in: Urban Policy System in Strategic Perspective: From V4 to Ukraine, ed. K. Glinka, Peter Lang Publishing, Berlin.

Glinka K. (2020e), Urban policy at the interface between the state and the city. The case of the Visegrad Group states and Ukraine, in: Urban Policy System in Strategic Perspective: From V4 to Ukraine, ed. K. Glinka, Peter Lang Publishing, Berlin.

Gonzalez Medina M., Fedeli V. (2015), Exploring European urban policy: Towards an EU-national urban agenda?, "Gestión y Análisis de Políticas Públicas", 14(14).

Government of the Republic of Poland (2020), Tarcza antykryzysowa. Samorzady, https://www.gov.pl/ web/tarczaantykryzysowa/dodatkowe-wsparcie-samorzady, 10.02.2021.

Holland B. (2015), Typologies of national urban policy: A theoretical analysis, "Cities", 48.

Honey-Roses J. et al. (2020), The Impact of COVID-19 on Public Space: A Review of the Emerging Questions, https://www.researchgate.net/publication/340819529_The_Impact_of_COVID19_ on_Public_Space_A_Review_of_the_Emerging_Questions, 10.11.2020.

Hooghe L., Marks G. (2003), Unraveling the Central State, but How? Types of Multi-Level Governance, "The American Political Science Review", 97, 2.

Howland D., Larsen Becker M., Prelli L. J. (2006), Merging Content Analysis and the Policy Sciences: A System to Discern Policy-Specific Trends from News Media Reports, "Policy Sciences", 39(3).

Idris J., Fagbenro A. (2019), Lagos the Mega-City: A Report on How the Metropolis Handled an Outbreak of the Ebola Epidemic, in: Socio-cultural Dimensions of Emerging Infectious Diseases in Africa. An Indigenous Response to Deadly Epidemics, eds. G. B. Tangwa, A. Abayomi, S. J. Ujewe, N. S. Munung, Springer.

Imbroscio D. L. (1998), Reformulating urban regime theory: The division of labor between state and market reconsidered, "Journal of Urban Affairs", 20.

Intitute of Regional and Urban Development (2020), Działania miast podczas pandemii, kwiecień 2020, http://obserwatorium.miasta.pl/wp-content/uploads/2020/04/Dzia\%C5\%82ania-miastpodczas-pandemii-marzec-2020-Grochowicz-Salata-Kochanowski-raport.pdf, 10.02.2021.

Ito N. C. et al. (2020), Public Capacity, Plural Forms of Collaboration, and the Performance of Public Initiatives: A Configurational Approach, "Journal of Public Administration Research and Theory", 30(4).

Jessop B. (2013), Hollowing out the 'Nation-State' and Multi-level Governance, in: A Handbook of Comparative Social Policy, ed. P. Kennet, Edward Elgar Publishing, Cheltenham.

Jones B., Keating M. (1995), The European Union and the Regions, Clarendon Press, Oxford.

Jones M. (2019), The Political Economy of Sub-National Economic Development, Edward Elgar Publishing.

Jordan A. (2001), The European Union. An evolving system of multi-level governance... or government?, "Policy \& Politics", 29, 2.

Kjaer A. M. (2009), Governance and the Urban Bureaucracy, in: Theories of Urban Politics, eds. J. S. Davies, D. L. Imbroscio, SAGE, Thousand Oaks, California.

Kjaer A. M. (2011), Rhodes' contribution to governance theory: Praise, criticism and the future governance debate, "Public Administration", 89(1).

Klimczuk-Kochańska M., Klimczuk A. (2016), Changes in the Local Government System and Regional Policy in Poland: The Impact of Membership in the European Union, in: Theoretical Foundations and Discussions on the Reformation Process in Local Governments, eds. U. Sadioglu, K. Dede, IGI Global, Hershey. 
KPMG (2020b), Poland. Government and institution measures in response to COVID-19, https:// home.kpmg/xx/en/home/insights/2020/04/poland-government-and-institution-measures-inresponse-to-covid.html, 10.11.2020.

Kraft M. E., Furlog S. R. (2021), Public policy. Politics, analysis, and alternatives, CQ Press, Thounsad Okas, California.

Lackowska M. (2010), Nowe interpretacje teoretyczne polityki wielkomiejskiej, "Studia Regionalne i Lokalne", 2.

Lackowska M. (2014), Miejska polityka ,,zagraniczna”. Koncepcja przeskalowania w doświadczeniach polskich miast, Wydawnictwo Uniwersytetu Warszawskiego, Warszawa.

Ladner A., Keuffer N., Baldersheim H. (2016), Measuring Local Autonomy in 39 Countries (19902014), "Regional \& Federal Studies", 26, 3.

Ladner A., Keuffer N., Baldersheim H., Hlepas N., Swianiewicz P., Steyvers K., Navarro C. (2019), Patterns of Local Autonomy in Europe. Governance and Public Management, Palgrave Macmillan, Cham.

Lam W. K., Zong N. S., Tam W. C. (2003), Overview on SARS in Asia and the World, "Respirology", $8(1)$.

Lawerack G., Manoncourt E. (2015), Key experiences of community engagement and social mobilization in the Ebola response, "Global Health Promotion", 23, 1.

Mair P. (1999), Searching for the Positions of Political Actors: A Review of Approaches and an Evaluation of Expert Surveys in Particular, https://ecpr.eu/Filestore/PaperProposal/fb463aa5-49d24ba6-8b88-aeca865ac475.pdf, 10.11.2020.

Masci J. R., Bass E. (2017), Ebola: Clinical Patterns, Public Health Concerns, CRC Press.

McKibbin W., Fernando R. (2020), The Global Macroeconomic Impacts of COVID-19: Seven Scenarios, https://www.brookings.edu/wp-content/uploads/2020/03/20200302_COVID19.pdf, 10.11.2020.

Młyniec E. (2004a), Aktor polityczny, in: Leksykon politologii, eds. A. Antoszewski, R. Herbut, Atla2, Wrocław.

Młyniec E. (2004b), Aktywność polityczna, in: Leksykon politologii, eds. A. Antoszewski, R. Herbut, Atla2, Wrocław.

Morton R. (1999), Methods and Models: A Guide to the Empirical Analysis of Formal Models in Political Science, Cambridge.

Morton R.(2009), Formal Modeling and Empirical Analysis in Political Science, in: Methoden der vergleichenden Politik- und Sozialwissenschaft, eds. S. Pickel, G. Pickel, D. Lauth, VS Verlag für Sozialwissenschaften.

Newing J., Fritsh S. (2009), The Case Survey Method and Applications in Political Science, https:// www.researchgate.net/publication/228162937_The_Case_Survey_Method_and_Applications_in_Political_Science, 11.11.2020.

Offe C. (2009), Governance: An "Empty Signifier”?, "Constellations”, 16(4).

Organisation for Economic Cooperation and Development (2020c), The impact of the COVID-19 crisis on regional and local governments, https://www.oecd.org/governance/the-impact-of-the-covid-19-crisis-on-regional-and-local-governments-fb952497-en.htm, 10.02.2021.

Organisation for Economic Cooperation and Development (2020d), Key impacts, http://www.oecd.org/ coronavirus/en/\#key-impacts, 10.11.2020.

Organisation for Economic Cooperation and Development (2020e), Key policy responses from the $O E C D$, http://www.oecd.org/coronavirus/en/policy-responses, 10.11.2020.

Pawłowska A., Kmieciak R., Kołomycew A., Radzik-Maruszak K., Antkowiak P. (2020), Społeczne rady i komisje jako (nie)obecny uczestnik lokalnego procesu decyzyjnego, Wydawnictwo Naukowe SCHOLAR, Warszawa. 
Peters B. G. (2019), American public policy: promsises and performances, SAGE, CQ Press, Los Angeles.

Poland.In. (2020), PM announces border lockdown, other virus countermeasures, https://polandin. com/47115218/pm-announces-border-lockdown-other-virus-countermeasures, 10.11.2020.

Qui W., Hu C., Mao A., Wu J. (2018), The Impacts on Health, Society, and Economy of SARS and H7N9 Outbreaks in China: A Case Comparison Study, "Journal of environmental and Public Health".

Radzik-Maruszak K. (2019), Rada gminy jako uczestnik lokalnego wspótrządzenia. Przykład Anglii, Finlandii, Polski i Stowenii, Wydawnictwo Naukowe SCHOLAR, Warszawa.

Rajca L. (2019), Reformy samorzadu terytorialnego na Wegrzech $i$ w Polsce, Elipsa, Warszawa.

Recommendations (2020), Rekomendacje postępowania w zwiazku z pandemia COVID-19, https:// www.gov.pl/web/gis/wiadomosci?page $=11 \&$ size $=10,10.02 .2021$.

Regulation (2020a), Journal of Laws 2020, item 566, REGULATION OF THE COUNCIL OF MINISTERS of March 31, 2020 on the establishment of certain restrictions, orders and bans in connection with an epidemic.

Regulation (2020b), Journal of Laws 2020, item 697, REGULATION OF THE COUNCIL OF MINISTERS of April 19, 2020 on the establishment of certain restrictions, orders and bans in connection with an epidemic.

Regulation (2020c), Journal of Laws 2020, item 491, Regulation of the Minister of Health of March, 20 2020 on the declaration of an epidemic in the territory of the Republic of Poland.

Regulation (2020d), Journal of Laws 2020, item 522, Regulation of the Minister of Health of March 24, 2020 amending the regulation on the declaration of an epidemic in the territory of the Republic of Poland.

Regulska A. (1993), Local government reform in Central and Eastern Europe, in: Local Government in the New Europe, J. R. Bennet, Belhaven Press, London.

Regulska J., Regulski J. (2000), Reforma samorzadowa w Europie Środkowej i Wschodniej-sukcesy i porazki, in: Europa Środkowo-Wschodnia, region, państwa i spoleczeństwa w czasie transformacji, ed. A. Rybczyńska, Wydawnictwo Uniwersytetu Marii Curie-Skłodowskiej w Lublinie, Lublin.

Regulski J. (1993), Rebuilding local government in Poland, in: Local Government in the New Europe, ed. J. R. Bennett, Belhaven Press, London-New York.

Regulski J., Kocon W. (1994), From Communism Towards Democracy: Local Government Reform in Poland, in: Local Government and Market Decentralization, ed. J. Benett, United Nations University Press, Tokyo-New York-Paris.

Rhodes R. A. W. (1994), The Hollowing Out of the State. The Changing Nature of the Public Service in Britain, "The Political Quarterly", 65(2).

Rhodes R. A. W. (1996), The New Governance: Governing without Government, "Political Studies", 44(4).

Rhodes R. A. W. (1997), Understanding Governance. Policy Networks, Governance, Reflexivity and Accountability, Open University Press, Buckingham.

Ribeiro H. V., Sunahara A. S., Sutton J., Perc M., Hanley Q. S. (2020), City size and the spreading of COVID-19 in Brazil, Cornell University, https://arxiv.org/abs/2005.13892, November, 10th 2020.

Sagan I. (2000), Miasto. Scena konfliktów i wspólpracy, Wydawnictwo Uniwersytetu Gdańskiego, Gdańsk.

Sroka J. (2008), Deliberacja i rządzenie wielopasmowe. Teoria i praktyka, Wydawnictwo Uniwersytetu Wrocławskiego, Wrocław.

Sroka J. (2018), Współdecydowanie w wielopasmowej polityce publicznej, Dom Wydawniczy Elipsa, Warszawa. 
Stier A. J., Berman M. G., Bettencourt L. M. A. (2020), COVID-19 attack rate increases with city size, Cornell University, https://arxiv.org/abs/2003.10376, 10.11.2021.

Stoker G., Mossberger K. (1994), Urban Regime Theory in Comparative Perspective, "Environment and Planning C: Government and Policy", 12(2).

Stoker G., Mossberger K. (2001), The Evolution of Urban Regime Theory: The Challenge of Conceptualization, "Urban Affairs Review", 36(6).

Stone C. N. (1989), Regime Politics: Governing Atlanta, 1946-1988, University Press of Kansas.

Stone C. N. (1993), Urban regimes and the capacity to govern: A political economy approach, "Journal of Urban Affairs", 15.

Swianiewicz P. (2005), Nowe interpretacje teoretyczne polityki miejskiej, "Studia Regionalne i Lokalne", 4(22).

Swianiewicz P. (2019), Zmiany w poziomie autonomii samorząów gminnych w Europie Środkowej i Wschodniej po 1990 roku, "Studia Politologiczne", 53.

Swyngedouw E. (1997), Neither global nor local: 'Glocalization' and the politics of scale, in: Space of globalization: Reasserting the power of the local, ed. K. R. Cox, Guilford Press.

Swyngedouw E. (2004), Globalisation or 'Glocalisation'? Networks, Territories and Rescaling, “Cambridge Review of International Affairs" 7(1).

Trzaskowska G. (2008), Epidemia czarnej ospy we Wroctawiu w 1963 r. Działania władz, akcja szczepień, funkcjonowanie szpitali ospowych w Szczodrem i Przaśniku oraz izolatoriów, Wrocław.

UNESCO (2020), Creative Cities' response to COVID-19, https://en.unesco.org/creative-cities/content/ cities-response-covid-19, 10.02.2021.

United Nations Procurement Division (2020), COVID-19 and Human Development: Assessing the Crisis, Envisioning the Recovery, http://hdr.undp.org/sites/default/files/covid-19_and_human_development_0.pdf, 10.11.2020.

United Nations (2020), United Nations: Policy Brief: COVID-19 in an Urban World, July 2020, https://www.un.org/sites/un2.un.org/files/sg_policy_brief_covid_urban_world_july_2020.pdf, 10.02.2021.

Wesley J. J. (2014), Qualitative Document Analysis in Political Science, in: From Text to Political Positions, eds. B. Kaal, I. Maks, A. van Elfrinkhof, John Benjamins Publishing Company, Amsterdam-Philadelpia.

World Bank (2020), Understanding the Coronavirus (COVID-19) pandemic through data, http:// datatopics.worldbank.org/universal-health-coverage/coronavirus/, 10.11.2020.

World Health Organization Europe (2020), City responses through COVID-19, https://www.euro.who. $\mathrm{int} / \mathrm{en} / \mathrm{health}$-topics/environment-and-health/urban-health/who-european-healthy-cities-network/the-who-european-healthy-cities-network-a-response-to-the-covid-19-pandemic-closeto-the-people/city-responses-through-covid-19, 10.02.2021.

World Health Organization (2020a), Transcript of UN Secretary-General's virtual press encounter to launch the Report on the Socio-Economic Impacts of COVID-19, https://www.un.org/sg/en/ content/sg/press-encounter/2020-03-31/transcript-of-un-secretary-general\%E2\%80\%99s-virtual-press-encounter-launch-the-report-the-socio-economic-impacts-of-covid-19, 10.11.2020.

World Health Organization (2020b), Strengthening preparedness for COVID-19 in cities and urban settings: interim guidance for local authorities, https://apps.who.int/iris/bitstream/handle/10665/331896/WHO-2019-nCoVUrban_preparedness-2020.1-eng.pdf? sequence $=1 \&$ isAllowed $=y, 10.02 .2021$.

Zimny-Zając A. (2020, August 18th), Lukasz Szumowski: Pierwsza fala pandemii jest już za nami, ale wirus nie znika, Onet.pl, https://www.medonet.pl/koronawirus/koronawirus-wpolsce,lukasz-szumowski--pierwsza-fala-jest-juz-za-nami--ale-wirus-nie-znika--goscmedonetu,artykul,86496654.html, 10.11.2020. 
Zybała A. (2012), Polityki publiczne. Doświadczenia w tworzeniu i wykonywaniu programów publicznych w Polsce $i$ w innych krajach, Krajowa Szkoła Administracji Publicznej, Warszawa.

Zybała A. (2013), Państwo i spoleczeństwo w działaniu. Polityki publiczne wobec potrzeb modernizacji państwa i spoleczeństwa, Wydawnictwo Difin, Warszawa.

\title{
Największe polskie miasta wobec pierwszej fali pandemii COVID-19. Perspektywa miejskiej administracji samorządowej
}

\begin{abstract}
Streszczenie
Celem artykułu jest analiza działań miejskiej administracji samorządowej ukierunkowanych na przeciwdziałanie destrukcyjnym skutkom pandemii COVID-19 w okresie tzw. pierwszej fali pandemii COVID-19 (marzec-czerwiec 2020). Artykuł koncentruje się na polskich miastach na prawach powiatu i przedstawia wyniki ogólnopolskiego badania ankietowego, w którym uczestniczyli przedstawiciele 47 urzędów miejskich, uzupełnione o analizę treści dokumentów (ustaw, rozporządzeń i zaleceń) oraz elementy analizy porównawczej. Przeprowadzone postępowanie badawcze nie pozwala na potwierdzenie hipotezy. Nie istnieje bowiem schemat reakcji na pandamię COVID-19, na który składają się działania miejskiej administracji samorządowej o "oddolnym" charakterze prowadzone w najbardziej doświadczonych przez pandemię COVID-19 obszarach polityki miejskiej. Okazuje się, że większość prowadzonych działań to działania "odgórne", które wpisują się - co wynika z odpowiedzi respondentów - w rozwiązania przyjęte przez centralną administrację rządową.
\end{abstract}

Słowa kluczowe: pandemia COVID-19, Polska, miasta, miejska administracja samorządowa 
